\title{
Evaluation of Mathematics teaching strategies in Australian High Schools
}

\author{
$\underline{\text { A.R. Alzahrani }}^{a}$ and E. Stojanovski ${ }^{\mathrm{a}}$ \\ ${ }^{a}$ School of Mathematical and Physical Sciences, University of Newcastle \\ Email: alirashashr.alzahrani@uon.edu.au
}

\begin{abstract}
Achievement in mathematics can act as an indicator of student ability in subjects that require mathematics proficiency such as science, technology and engineering. Analysis of data from the Programme for International Student Assessment 2012 study on high school students from Australia was performed to evaluate the potential effects of various teaching strategies on mathematics outcomes. Aspects of teaching considered included student-teacher relations, classroom management, teacher support, disciplinary climate, cognitive activation, formative assessment, student orientation, and teacher directed instruction. Parent education levels and economic status were also considered as potential influences of performance and were found to have significant effects on mathematics performance with students whose parents were more highly educated recording higher results, on average. Cognitive activation, disciplinary climate, student-teacher relations, and vignette classroom management were found to have a significant positive impact on mathematics performance. Student orientation had a significant negative effect on mathematics performance and greater use of it was associated with lower mathematics achievement. The results of this study can offer valuable insights into how teaching strategies, along with other factors, can be augmented to help improve confidence in, and hence, performance in mathematics.
\end{abstract}

Keywords: $\quad$ Multilevel modelling, teaching strategies, mathematics 


\section{INTRODUCTION}

Teachers and the strategies they employ for mathematics instruction have been found to affect mathematics performance (Hill et al, 2008). Alzahrani et al (2017) found different teaching methods to have different associations with mathematics outcomes, and specifically, that cognitive-based teaching approaches appeared to enhance mathematics performance among students. Teacher characteristics, among them, the ability to meaningfully interact and relate with students, and teacher self-efficacy beliefs, have also been found to have a profound impact on student mathematics performance (Rockstroh, 2013). This is supported by the research of Toropova et al (2019) and Buddin and Zamarro (2010) who found a positive relationship between student mathematics achievement and teacher quality indicators such as teaching experience. Teaching strategies and teacher characteristics are hence potentially important aspects that can impact student achievement in mathematics. As a result, there is an increased need to develop teaching practices to achieve positive outcomes in mathematics and statistics education. An improvement in methods of mathematics teaching in schools is essential to help motivate students to undertake science, technology, engineering and mathematics related courses at university (Manyika et al, 2011). Furthremore, effective teaching is an integral factor in providing required knowledge and skills in statistics, considered a strand of mathematics. Accordingly, it is necessary to examine teaching practices that instructors employ and their effects in terms of supporting and motivating learners (Lamy and Steve, 2016).

The Programme for International Student Assessment (PISA) is an international study that focuses on learning outcomes of students. An added focus of the 2012 PISA study was to examine and understand mathematics performance and factors affecting it for Australian school student (OECD, 2014). An understanding of the effect of teaching strategies on student learning, and, in particular, on the ability of students to apply mathematical concepts in exams and their daily lives, is a motivation to assess the role of teaching methods in supporting students and promoting positive outcomes among students. The present study will investigate the effects of teaching strategies as well as factors including parental education and socio-economic status on mathematics performance in Australia.

\section{METHODOLOGY}

Data obtained from the 2012 PISA study for Australia is analysed for the current study. PISA 2012 data for Australia was collected from a total of 14,481 students drawn from 775 schools that participated in the study (Thomson et al, 2013). The nationally representative random sample for the PISA study in Australia was based on students aged 15 years drawn from schools across the country. To further ensure the ability of the random sample of Australian students participating in the study to generate reliable national estimates for the population, a larger sample was obtained for sections of the country with indigenous students with smaller jurisdictions being oversampled. Data in Australia for the PISA study was collected from late July to early September 2012, a period prior to which those administering the test were coached in PISA procedures to ensure the assessment was conducted in a manner that was consistent and standard (Thomson et al, 2013).

While the PISA 2012 study sought to assess reading, scientific and mathematical literacy of students and their capacity to apply related skills and knowledge to real-life situations and problems, the focus of the present study is on mathematical literacy, which was the chief domain of the assessment in 2012 PISA Measures of ratings by students of factors such as teaching approaches that affect learning ability of Australian students were considered. To establish the impact of teaching strategies on mathematics outcomes, instructional approaches used by Australian teachers were considered and their effects based on individual student rating determined. Performance of students in mathematics was quantified based on the number of test questions that were correctly answered and real-life problems that were correctly solved using mathematical concepts. Final scores for mathematical literacy were standardised for all participating countries with a mean score of 504 points and a standard deviation of 92 for this domain. Australia recorded an average score that was significantly higher than that of most of the other participating countries, particularly when compared with the OECD countries, which recorded a mean score of 494 points (Thomson et al,2013). Demographic information for participating Australian students was also obtained for the purposes of assessing parental socio-economic status and education levels and estimating the impact these variables have on mathematic outcomes among students. The measures for these variables were recorded on a Likert scale from 0 to 6 ; with 6 denoting the highest level of parental education.

For the present study, the effects of eleven teaching strategies are evaluated. A subscale made up of several distinct items in the questionnaire administered to students is employed to measure each teaching strategy. These scales and subscales are listed in Table 1.The components of the following teaching strategy domains were considered and measured on a scale from 1 to 4 and the average was calculated for each subscale: 
Attributions To Failure measured the quality of teacher explanation and ability of teacher to keep students engaged; Math Teaching measured by teacher helps, shows interest and expresses opinions; Teacher-Directed Instruction measured whether teacher explains learning goals; Student orientation measured by teacher assigning different tasks to different students, has students work in small groups, and if students are involved in planning; Formative Assessments measured by planning in class activities, highlight expectations, and advice on improvement; Cognitive Activation teacher provides multiple solution problems and encourages students to use own procedures; Disciplinary Climate by students attentive, orderly and work late; Vignette Teacher Support measured by: whether teacher gives homework and feedback; Teacher Support measured by items: teacher motivates, assists and gives opportunity; Vignette Classroom Management measured by students calm and teacher arrives on time; Classroom Management measured by: whether teacher starts on time, keeps class orderly and students listen; and lastly, Student-Teacher Relations measured by: whether teacher is fair, interested, helps and listens to students. Mother and father education levels were measured by the items presented in Table 2 .

A test for multicollinearity among individual measures of teaching subscales was conducted by assessing correlations among subscales of teaching strategies. All correlation coefficients between teaching strategy subscales were of magnitude 0.68 or less; indicating that multicollinearity was not a concern for the associated analyses. Multilevel regression modelling was used to evaluate the effect of teaching strategies on mathematics performance. This approach allows for evaluation of hierarchies in the data. Random effects are incorporated into the model for the school level data while student level data will account for the expected higher correlations on measures among students in the same school. Schools are treated as random effects in the models while teaching strategies, parent socio economic status and parent education level variables were considered in the model as fixed effects, to assess their association with the outcome variable, mathematics performance for students in Australia.

Table 1. List of teaching strategy scales considered

\begin{tabular}{|l|l|}
\hline Teaching Subscale & Items \\
\hline Attributions to failure & $\begin{array}{l}\text { Teacher did not explain well } \\
\text { Teacher did not get students interested }\end{array}$ \\
\hline Maths teaching & $\begin{array}{l}\text { Teacher shows interest } \\
\text { Extra help } \\
\text { Teacher helps } \\
\text { Teacher continues teaching until students understand } \\
\text { Gives students opportunity to express opinions }\end{array}$ \\
\hline Teacher directed instruction & $\begin{array}{l}\text { Sets clear goals } \\
\text { Encourages thinking and reasoning } \\
\text { Checks understanding } \\
\text { Summarizes previous lessons } \\
\text { Informs about learning goals }\end{array}$ \\
\hline Student orientation & $\begin{array}{l}\text { Differentiates between students when giving tasks } \\
\text { Assigns complex projects } \\
\text { Has students work in small groups }\end{array}$ \\
\hline Formative Assessment & $\begin{array}{l}\text { Plans classroom activities } \\
\text { Gives feedback on strengths \& weaknesses } \\
\text { Informs about expectations } \\
\text { Tells how to get better }\end{array}$ \\
\hline Cognitive activation & $\begin{array}{l}\text { Teacher encourages to reflect on problems } \\
\text { Gives problems that require to think } \\
\text { Asks to use own procedures } \\
\text { Presents problems with no obvious solutions } \\
\text { Presents problems in different contexts } \\
\text { Helps learn from mistakes } \\
\text { Asks for explanations } \\
\text { Apply what we learned } \\
\text { Problems with multiple solutions }\end{array}$ \\
\hline & \\
\hline
\end{tabular}


Alzahrani and Stojanovski, Evaluation of Mathematics teaching strategies in Australian High Schools

\begin{tabular}{|l|l|}
\hline Disciplinary climate & $\begin{array}{l}\text { Students don't listen } \\
\text { Noise and disorder } \\
\text { Teacher has to wait until it is quiet } \\
\text { Students can't work well } \\
\text { Students don't start working for a long time after the } \\
\text { lesson begins }\end{array}$ \\
\hline Vignette teacher support & $\begin{array}{l}\text { Homework every other day/back in time } \\
\text { Homework once a week/back in time } \\
\text { Homework once a week/not back in time }\end{array}$ \\
\hline Teacher support & $\begin{array}{l}\text { Let us know we have to work hard } \\
\text { Provides extra help when needed }\end{array}$ \\
& $\begin{array}{l}\text { Helps students with learning } \\
\text { Gives opportunity to express opinions }\end{array}$ \\
\hline Vignette classroom & $\begin{array}{l}\text { Students frequently interrupt/teacher arrives late } \\
\text { management }\end{array}$ \\
& $\begin{array}{l}\text { Students frequently interrupt/teacher arrives early } \\
\text { Students are calm/teacher arrives on time }\end{array}$ \\
\hline Classroom management & $\begin{array}{l}\text { Students listen } \\
\text { Teacher keeps class orderly } \\
\text { Teacher starts on time } \\
\text { Wait long to < quiet down }>\end{array}$ \\
\hline Student teacher relations & Get along with teachers \\
& $\begin{array}{l}\text { Teachers are interested } \\
\text { Teachers listen to students } \\
\text { Teachers help students } \\
\text { Teachers treat students fair }\end{array}$ \\
\hline
\end{tabular}

Table 2. Scale used to measure Parent educational level

\begin{tabular}{|c|l|}
\hline Level & Parents educational level \\
\hline 0 & Primary Education is not completed. \\
\hline 1 & Primary Education is completed \\
\hline 2 & Secondary education is completed \\
\hline 3 & Upper Secondary education is completed \\
\hline 4 & Non-tertiary post-secondary education is completed \\
\hline 5 & Non-tertiary university education is completed \\
\hline 6 & Qualified in advanced research programmes (post-graduate) or completed university level tertiary education \\
\hline
\end{tabular}

\section{RESULTS}

Results from the multilevel regression model with schools from which the population sampled was drawn treated as random effects, are reported in Table 3. Parental socioeconomic status (SES) and each subscale of the teaching strategies was then assessed against mathematics performance. It was found that Attributions to Failure, Formative Assessment and Vignette Teacher Support were not significant predictors of mathematics performance $(p>0.05)$. It was also established that parental education level and parental socio-economic status were significantly and positively associated with student mathematics outcome $(p<0.001)$.

Table 3. Bivariate analyses of each teaching strategy and SES by mathematics score

\begin{tabular}{|l|c|c|c|c|c|}
\hline \multicolumn{1}{|c|}{ Effect } & Estimate & $\begin{array}{c}\text { Standard } \\
\text { Error }\end{array}$ & DF & $\boldsymbol{t}$-Value & $\boldsymbol{p}$-value \\
\hline Socioeconomic Statusv(SES) & 0.16 & 0.007 & 143 & 22.62 & $<.0001$ \\
\hline Attributions to Failure & 0.004 & 0.002 & 8619 & 1.57 & 0.1173 \\
\hline Maths Teaching & 0.03 & 0.002 & 8545 & 12.18 & $<.0001$ \\
\hline Teacher Directed Instruction & 0.03 & 0.003 & 8560 & 8.72 & $<.0001$ \\
\hline Student orientation & -0.05 & 0.003 & 8550 & -14.02 & $<.0001$ \\
\hline
\end{tabular}




\begin{tabular}{|l|c|c|c|c|c|}
\hline Formative Assessment & -0.001 & 0.002 & 8567 & -0.38 & 0.7047 \\
\hline Cognitive Activation & 0.03 & 0.003 & 8570 & 10.27 & $<.0001$ \\
\hline Disciplinary climate & 0.06 & 0.002 & 8558 & 25.03 & $<.0001$ \\
\hline Vignette Teacher Support & -0.002 & 0.004 & 8552 & -0.43 & 0.6682 \\
\hline Teacher Support & 0.04 & 0.003 & 8527 & 11.36 & $<.0001$ \\
\hline Vignette classroom management & 0.13 & 0.004 & 8478 & 32.77 & $<.0001$ \\
\hline Classroom Management & 0.06 & 0.003 & 8578 & 17.99 & $<.0001$ \\
\hline Student Teacher Relation & 0.06 & 0.004 & 8557 & 15.76 & $<.0001$ \\
\hline
\end{tabular}

After adjusting for each teaching strategy subscale, and socioeconomic status, teaching strategy subscales including student orientation, cognitive activation, disciplinary climate, vignette classroom management and student-teacher relations remained statistically significant predictors of mathematics performance among students in Australia. In the reduced model, where non statistically significant variables from the model presented in Table 4 were removed, the effects of math teaching strategies, teacher directed instructions, teacher support and classroom management on mathematics performance among 15 -year old students in Australia were no longer statistically significant ( $p$-values of $0.62,0.69,0.36$ and 0.28 respectively).

Table 4. All significant teaching strategies fitted in one model assessing their significance

\begin{tabular}{|l|c|c|c|c|c|}
\hline Effect & Estimate & $\begin{array}{c}\text { Standard } \\
\text { Error }\end{array}$ & DF & t Value & Pr $>|\mathbf{t}|$ \\
\hline Intercept & -0.083 & 0.018 & 771 & -4.41 & $<.0001$ \\
\hline Maths Teaching & 0.002 & 0.004 & 8348 & 0.49 & 0.62 \\
\hline Teacher Directed Instruction & 0.002 & 0.005 & 8348 & 0.39 & 0.69 \\
\hline Student Orientation & -0.056 & 0.004 & 8348 & -14.62 & $<.0001$ \\
\hline Cognitive Activation & 0.031 & 0.005 & 8348 & 6.51 & $<.0001$ \\
\hline Disciplinary Climate & 0.051 & 0.003 & 8348 & 15.38 & $<.0001$ \\
\hline Teacher Support & -0.005 & 0.005 & 8348 & -0.91 & 0.36 \\
\hline Vignette Classroom Management & 0.102 & 0.004 & 8348 & 24.57 & $<.0001$ \\
\hline Classroom Management & -0.006 & 0.005 & 8348 & -1.07 & 0.28 \\
\hline Student Teacher Relation & 0.04 & 0.004 & 8348 & 8.76 & $<.0001$ \\
\hline
\end{tabular}

This model was further reduced to reflect only the teaching strategies that were statistically significant from the adjusted model and is presented in Table 5. The remaining teaching strategy subscales in Table 5 remained statistically significant and positively associated with mathematics performance, except student orientation was negatively associated with mathematics performance. Other predictor variables considered in the model were parental socio-economic status and parental education levels, which also remained statistically significant predictors of mathematics performance.

Table 5. Final model depicting strategies whose effect remained significant in the adjusted model

\begin{tabular}{|l|c|c|c|c|c|}
\hline \multicolumn{1}{|c|}{ Effect } & Estimate & $\begin{array}{c}\text { Standard } \\
\text { Error }\end{array}$ & DF & t-Value & $\boldsymbol{p}$-value \\
\hline Intercept & -0.092 & 0.018 & 771 & -5.00 & $<.0001$ \\
\hline Student Orientation & -0.054 & 0.003 & 8405 & -14.96 & $<.0001$ \\
\hline Cognitive Activation & 0.029 & 0.004 & 8405 & 7.75 & $<.0001$ \\
\hline Disciplinary Climate & 0.049 & 0.003 & 8405 & 18.48 & $<.0001$ \\
\hline Vignette Classroom Management & 0.102 & 0.004 & 8405 & 24.92 & $<.0001$ \\
\hline Student Teacher Relation & 0.038 & 0.004 & 8405 & 8.86 & $<.0001$ \\
\hline Socio-Economic Status & 0.097 & 0.010 & 7448 & 9.13 & $<.0001$ \\
\hline Father Qualification Level & 0.016 & 0.001 & 7448 & 10.93 & $<.0001$ \\
\hline Mother Qualification Level & 0.012 & 0.001 & 7448 & 7.79 & $<.0001$ \\
\hline
\end{tabular}


Australian students assessed in PISA 2012 recorded an improvement in mathematics performance when cognitive activation was utilised. Better performance was also found when disciplinary climate, student-teacher relations, and vignette classroom management strategies were implemented during which students listened, classes were orderly, teachers arrived early for lessons and students got along well with the teachers. Vignette classroom management appears to have the most positive influence on mathematics achievement, indicating that a calm and orderly class whereby the teacher arrives on time to class, is associated with better achievement. The effects of math teaching, teacher directed instructions, teacher support and classroom management on mathematics performance were not statistically significant in comparison to student orientation, cognitive activation, disciplinary climate, vignette classroom management and student-teacher relations. Student orientation appeared to have a negative impact on mathematics performance and greater use of student orientation was associated with lower mathematics achievement. The relationship of student orientation with mathematics performance, however, should not be interpreted as causal. Greater use of student orientation does not necessarily result in lower performance. Rather, this outcome may reflect the use and/or the efficiency of the strategy with_particular student groups that was not investigated as part of this study. Parental SES and education levels also significantly affected mathematics performance. Therefore, while PISA 2012 data on Australian students supports the use of some teaching strategies, and SES as important predictors of mathematics performance, further analysis is needed to better establish how individual student factors interact with a combination of teaching and non-teaching strategy elements to influence mathematics performance.

\section{REFERENCES}

Alzahrani, A., Stojanovski, E., \& Howley, P. (2017). Assessment of Teaching Practices on Mathematics for Students in Qatar. Proceedings of the International Association for Statistics Education (IASE).

Buddin, R., \& Zamarro, G. (2010). What Teacher Characteristics Affect Student Achievement? Research Briefs, https://www.rand.org/pubs/research_briefs/RB9526.html.

Hill, H. C., Blunk, M. L., Charalambous, C. Y., Lewis, J. M., Phelps, G. C., Sleep, L., \& Ball, D. L. (2008). Mathematical knowledge for teaching and the mathematical quality of instruction: An exploratory study. Cognition and Instruction, 26(4), 430-511

Lamy, M., \& Steve M. (2016), Why Students Are Motivated To Learn Maths, PISA 2012: Series on Learners, $3,10-20$.

Manyika, J., Chui, M., Brown, B., Bughin, J., Dobbs, R., Roxburgh, C., Byers, A. H. (2011). Big data: The next frontier for innovation, competition, and productivity. McKinsey Global Institute. Online at http://www.mckinsey.com/business-functions/digital-mckinsey/our-insights/big-data-the-nextfrontier-for-innovation

OECD. (2014). PISA 2012 Results in Focus: What 15-year-olds know and what they can do with what they know. https://www.oecd.org/pisa/keyfindings/pisa-2012-results-overview.pdf.

Rockstroh, A. H. (2013). Teacher Characteristics on Student Achievement: An Examination of High Schools in Ohio. MPA/MPP Capstone Projects , 49, https://uknowledge.uky.edu/mpampp_etds/49.

Thomson, S., Bortoli, L. D., \& Buckley, S. (2013). PISA 2012 : how Australia measures up : the PISA 2012 assessment of students' mathematical, scientific and reading literacy. Victoria: Australian Council for Educational Research.

Toropova, A., Johansson, S., \& Myrberg, E. (2019). The role of teacher characteristics for student achievement in mathematics and student perceptions of instructional quality. Education Inquiry, DOI: 10.1080/20004508.2019.1591844.

Wang, C., Chen, M.-H., Schifano, E., Wu, J., \& Yan, J. (2016). Statistical methods and computing for big data. Stat Interface , 9 (4), 399-414. 